\title{
Preface
}

\section{Editorial Procedures}

I have limited my selections to works that appeared in English between approximately 1550 and 1735 , to concentrate on the representations available to the greatest number of literate English men and women. For modern translations of a far wider range of material, including texts in Latin not translated in the period and those in other European vernaculars, see Kenneth Borris's Same-Sex Desire in the English Renaissance: A Sourcebook of Texts, 1470-1650 (Routledge, 2004). I have modernized each of the texts selected below, normalizing spelling, capitalization, and punctuation, except in particular cases; thus, original spelling has been maintained in poetry, for example, when rhyme or scansion demanded it; dialect forms have also been maintained as far as possible. I have not maintained the originals' use of italics. Readers interested in facsimile editions of some of the works selected for this anthology should examine Alexander Pettit and Patrick Spedding's excellent ten-volume collection Eighteenth-Century British Erotica, Parts I and II, particularly part 2, volume 5 (on homosexuality edited by Rictor Norton) and part 1, volume 2 (edited by Kevin L. Cope). For a wealth of material on homosexuality in the eighteenth century, readers should consult Rictor Norton's online Homosexuality in Eighteenth-Century England: A Sourcebook (see Works Cited). For the more obscure works selected below, I include a list of available editions.

\section{Annotations and Glossary}

Proper names that occur frequently throughout the anthology have been gathered together in a glossary: these include figures from classical mythology 
and literature (such as Apollo, Achilles, Danae, Elysium, the Furies, etc.), and historical figures from classical antiquity (such as Socrates, Plato, and Heliogabalus), as well as biblical figures (such as David and Jonathan). All other people, places, and things, as well as early modern historical and literary figures are identified in the footnotes.

\section{Cross-References}

Each selection has been assigned a number to make cross-references easier to use. Thus, Sappho's poem 'Hymn to Venus' is cross-referenced as follows: 7.5.2, where '7' refers to 'Chapter 7: The Classical Tradition in Translation'; '5' refers to the fifth selection in this chapter 'John Addison's Works of Anacreon [...] and Sappho'; and '2' refers to the second poem in this selection, 'Hymn to Venus'. Cross-references within a particular selection will simply refer the reader, for example, to $\mathbf{n} 3$.

\section{Reference Works}

Unless otherwise noted, headnotes and annotations rely on the following.

1. Definitions of words and phrases: Oxford English Dictionary (second online edn; accessed 2010); E. Knowles's Oxford Dictionary of Phrase and Fable (online edn, 2006); E. Partridge's Dictionary of Slang (ed. P. Beale, eighth edn, 2002); G. Williams's Dictionary of Sexual Language and Imagery in Shakespearean and Stuart Literature, 2 vols (1994).

2. Classical, literary, and historical figures: Oxford Classical Dictionary (third edn, 1999); G. Speake's Penguin Dictionary of Ancient History (1994); Oxford Companion to Classical Literature (1984); B. Radice's Penguin Who's Who in the Ancient World (1973); J. Lemprière's Classical Dictionary (1788; rept, 1994).

3. The Bible and Christianity: HarperCollins' Bible Dictionary (gen. ed. P.J. Achtemeier, rev. edn, 1996); W.R.F. Browning's Oxford Dictionary of the Bible (1996); Harper's Bible Commentary (gen. ed. J.L. Mays, 1988); Oxford Dictionary of the Christian Church (ed. F.L. Cross and E.A. Livingstone, second rev. edn, 1983).

4. Same-sex lovers in history: J.G. Younger's Sex in the Ancient World, from A-Z (2005); Who's Who in Gay E Lesbian History: From Antiquity to World War II (ed. R. Aldrich and G. Wotherspoon, 2002).

5. Early modern England's society, history, and culture: Marcel De 
Cleene and Marie Claire Lejeune's Compendium of Symbolic and Ritual Plants in Europe, 2 vols (1999-2003); L.W. Cowrie's Wordsworth Dictionary of British Social History (1996); M.B. Picken's Dictionary of Costume and Fashion: Historic and Modern (1985; rept, 1998); The Diary of Samuel Pepys, Vol. X, Companion (ed. R.C. Latham and W. Matthews, 1971); M.P Tilley's Dictionary of the Proverbs in England in the Sixteenth and Seventeenth Centuries (1966); C.W. Cunnington's Dictionary of English Costume (1960); Calendar of State Papers, Domestic series [of the Commonwealth] 1649-1660 (ed. M.A.E. Green, 1875-1886); Pliny's Natural History, 2 vols (trans. P. Holland, 1601).

6. Biographical information on early modern figures: Oxford Dictionary of National Biography (DNB: online edn, accessed 2011); Burke's Peerage, Baronetage E Knightage (ed. C. Mosley, 107th edn, 3 vols, 2003); Alumni Cantabrigiensis, 4 vols (ed. J. Venn, 1922-7); The Eton College Register, 1441-1698 (ed. W. Sterry, 1943).

Unless otherwise noted, references to Greek and Latin texts are to the standard Loeb editions.

\section{Online Companion}

Reducing an anthology that once stood at approximately 500,000 words to its present length was a challenge. There are far more texts concerning early modern same-sex erotic relationships and desires than can be contained within a relatively brief anthology. Interested readers may consult the Online Companion for additional texts and brief interpretative essays at: http://hdl. handle.net/2429/43470.

\section{Acknowledgements}

The editor sincerely thanks all who helped with this project, particularly the following: my insightful and painstaking graduate research assistants, Jannik Eikenaar and Kelly Doyle, my equally conscientious undergraduate research assistant, Richard Benade, and the Work Study Program as well as the Department of Critical Studies (Faculty of Creative and Critical Studies, University of British Columbia-Okanagan) for jointly funding their positions; the helpful librarians and staff at the Bodleian Library, British Library, Folger Shakespeare Library, Wellesley College Library, and Huntington Library; Professors Rictor Norton and Rosalind Ballaster (Mansfield College, Oxford 
University) for their kind encouragement; Professor W.R. Jones (University of Leicester) for his information about Lucian's translator, Thomas Brown; Professors Peter Sabor (McGill University) and Thomas Keymer (University of Toronto) for their assistance with The Sappho-An; Professor Michael Treschow (UBC-Okanagan) for his generous assistance with Ovid's Latin; my Manchester editors, Matthew Frost, Kim Walker, and Lianne Slavin for their patience and support; John Banks for his painstaking copyediting; and finally my family, without whose forbearance this book would still be unfinished. 